\title{
The Application of WeChat Public Platform in College English Teaching
}

\author{
Li Chen \\ School of Foreign Languages, Wuhan Polytechnic University, Wuhan, Hubei, China \\ 99759484@qq.com
}

Keywords: WeChat public platform; College English teaching

\begin{abstract}
In recent years, the development and popularization of WeChat has been recognized by the vast numbers of users. Due to the penetration of WeChat on mobile phones all around the China, tremendous attention has been attached to the application of WeChat in foreign language teaching. College students who are interested in novel things in fashion and crazy about "in" electronic communicative medium, own smart mobile phones together with enough flows and possess relatively discretionary and controllable after-class time. Applying WeChat Public Platform to College English teaching is practical due to its easy operation and tiny expense. This paper analyzes the function of WeChat Public Platform and how to apply it to College English teaching.
\end{abstract}

\section{Introduction}

College English Curriculum Requirements of China (2007) demands that the colleges and universities in China should "extensively use the advanced information technology, develop and construct a variety of computer-based networked courses, provide students with good English learning environment and conditions", which affirms the necessity of the new multimedia-assisted language teaching model, requiring "all colleges and universities should make full use of modern information technology, change the single teacher-oriented teaching mode by computer-based classroom teaching of English. On the basis of modern information technology, especially network technology, the new teaching model makes the teaching and learning of English free of time and place constraints, developing towards the direction of personalization and self-learning." The network-based foreign language teaching, especially WeChat Public Platform, expands time and space of teaching.

\section{Function of WeChat Public Platform}

WeChat provides multimedia communication flexibility and convenience with text messaging, hold-to-talk voice messaging, broadcast (one-to-many) messaging, photo/video sharing, location sharing, and contact information exchange. WeChat also supports social networking via shared streaming content feeds and location-based social plug-ins ('Shake', 'Look Around', and 'Drift Bottle') to chat with and befriend local and international WeChat users. Photos can be taken and embellished with artistic filters, captioned and put into a personal photo journal, and distributed to friends. User data is protected via on-demand contact list backup and retrieval to/from a cloud-based service. With the above features, WeChat provides a complete, robust, and secure social networking platform that emphasizes user privacy and fast response performance.

WeChat supports users to register as a public platform of which is an application called WeChat public platform enabling public platforms to push feeds to subscribers, interact with subscribers and provide them with services in the following year ${ }^{[10]}$ It is reported that the market penetration reached 93\% of China mainland in a recent study investigated by the market research company-On Device. By Jun, 2015, active users of WeChat had exceeded 6 million all over the world. The extreme popularity is the exact reason why we select WeChat public platform as stable technical support. On one hand, WeChat public platform provide a fresh approach to College English teaching; on the other hand, it is of rather convenience for instant and dynamic learning. 


\section{Advantages of the Application of WeChat Public Platform in College English Teaching}

The combination of WeChat Public Platform and College English teaching is one of the most popular trends of the development of foreign language teaching, because compared with the traditional teaching mode and other media, WeChat Public Platform has many advantages in College English teaching.

Providing an Excellent English Learning Environment. In the traditional teaching activities, teachers and students constitute the teaching system together. However, teachers are always in the dominant position. The quantity of teaching information is small in class and the English teaching environment is very narrow, so students are lack of enthusiasm and real language environment to speak and learn English. It doesn't adapt to the foreign language teaching requirements which regard students as the main body. Students can choose the corresponding language input according to his real English level and allocate the reasonable study time on the basis of their learning process. WeChat Public Platform breaks the one-way communication mode; it puts more emphasis on the discussion and interaction.

Stimulating Students' Interest in English Learning. There is no denying that students' interest and emotion is essential in learning process. So college English teachers must pay attention to students' emotion and create a relaxing, democratic and harmonious teaching atmosphere. The positive emotion promotes the English learning while the negative ones influence the learning effect as well as the long development of students. By applying WeChat Public Platform, teachers can create a lively learning environment, improve teaching efficiency and teaching quality because network-assisted teaching integrates the technology of texts, graphics, images, animation, video and audio, which increases sensory stimulation of students and makes the teaching figurative, three-dimensional and vivid, thereby increasing students' interest in learning.

Enhancing the Interaction Between Students and Teacher. With people paying more attention to the emotional communication between teachers and students in colleges and universities, promoting the emotional communication between teachers and students has become an important part of college education. WeChat Public Platform provides a platform for communication and interaction between teachers and students. In order to understand students' learning level and problems and to participate in the activities of students based on group, college English teachers can hold one-to-one private communication with students and many-to-many group communication through personal WeChat ${ }^{[1]}$. College English teachers can use WeChat Public Platform to understand the status of the student's thought and to offer help timely, making up for emotion absence in traditional classroom teaching, which improve the relationship between teachers and students ${ }^{[2]}$. From the perspective of the students, teachers' guidance and help in WeChat Public Platform greatly enhances students' emotional satisfaction and promote the enthusiasm of the students to learn English.

\section{How to Apply WeChat Public Platform to College English Teaching}

Starting from April 2017, the author's research group created "micro English learning" WeChat Public Platform to assist college English teaching. The teaching practice lasted five weeks. This teaching practice carried out in accordance with the normal teaching progress. A-level students were asked to subscribe WeChat Public Platform New Horizon College English was used as the teaching material, consistent with the other B-level students. Concrete and classroom interaction steps are as Table 1: 
Table 1 Steps of applying WeChat public Platform to college English teaching

\begin{tabular}{|c|c|c|c|}
\hline & Learning form & Learning phase & Learning environment \\
\hline $\begin{array}{c}\text { Step } \\
1\end{array}$ & $\begin{array}{l}\text { Self-study based on the } \\
\text { information delivered by } \\
\text { WeChat Public Platform }\end{array}$ & Preview & WeChat Public Platform \\
\hline $\begin{array}{l}\text { Step } \\
2\end{array}$ & Lectures given by teacher & Classroom learning & Multimedia classroom \\
\hline $\begin{array}{l}\text { Step } \\
3\end{array}$ & $\begin{array}{l}\text { Self-study based on the } \\
\text { information delivered by } \\
\text { WeChat Public Platform }\end{array}$ & $\begin{array}{l}\text { Problem, task oriented } \\
\text { learning after class }\end{array}$ & WeChat Public Platform \\
\hline $\begin{array}{c}\text { Step } \\
4\end{array}$ & $\begin{array}{l}\text { Classroom discussion } \\
\text { organized by teacher }\end{array}$ & $\begin{array}{l}\text { Further discussion of the } \\
\text { works in the classroom }\end{array}$ & Multimedia classroom \\
\hline $\begin{array}{l}\text { Step } \\
5\end{array}$ & $\begin{array}{l}\text { Self-study based on the } \\
\text { information delivered by } \\
\text { WeChat Public Platform }\end{array}$ & $\begin{array}{l}\text { Modify its work according } \\
\text { to the results of the } \\
\text { discussion }\end{array}$ & WeChat Public Platform \\
\hline $\begin{array}{l}\text { Step } \\
6\end{array}$ & $\begin{array}{l}\text { Participatory learning } \\
\text { based on the information } \\
\text { delivered by WeChat } \\
\text { Public Platform }\end{array}$ & $\begin{array}{l}\text { Complete group tasks after } \\
\text { learning all the knowledge }\end{array}$ & WeChat Public Platform \\
\hline $\begin{array}{l}\text { Step } \\
7\end{array}$ & $\begin{array}{l}\text { Participatory learning } \\
\text { based on the information } \\
\text { delivered by WeChat } \\
\text { Public Platform }\end{array}$ & $\begin{array}{l}\text { Group modify according to } \\
\text { teacher and students' advice }\end{array}$ & WeChat Public Platform \\
\hline $\begin{array}{c}\text { Step } \\
8\end{array}$ & $\begin{array}{l}\text { Classroom score } \\
\text { organized by teacher }\end{array}$ & $\begin{array}{l}\text { Evaluate the achievements } \\
\text { of group study }\end{array}$ & Multimedia classroom \\
\hline
\end{tabular}

After determining the teaching content, English teacher uses WeChat Public Platform as a platform to assist classroom teaching. In the whole process, teacher gives full play to its leading role and plans the learning points and theme, suitable for WeChat Public Platform to learn according to the relevant contents of classroom teaching. According to students' feedback, after applying WeChat Public Platform, A-level students achieved a lot in many aspects, such as self-confidence, language proficiency and communication skills.

\section{Some Suggestions on the Application of WeChat Public Platform in College English Teaching}

Classroom Teaching is Center While WeChat Public Platform is Assistance. Applying WeChat Public Platform to college English classroom teaching has brought new advantages for network foreign language education. Using WeChat Public Platform as a platform for students' interactive learning is a new form of college English teaching under the network environment. However, WeChat Public Platform cannot fully replace the traditional classroom teaching, and it must give priority to classroom teaching; At the same time in order to prevent the situation that learning becomes a mere formality, teacher should timely constraint, supervise and regulate students' using of WeChat Public Platform .

Teacher Should Pay Attention to Learning Evaluation. WeChat Public Platform expands the time and space of the college English teaching. When students are taken as the main body, students' subjective initiative can be effectively developed. But students' using of WeChat Public Platform must be comprehensively evaluated (such as learning behavior, learning process and learning result). This is helpful to construct a learning community who have a common desire, to cultivate students' learning quality (such as share, trust and belonging), for students to adapt to the networked education teaching methods and teaching means.

Time Must be Fixed When Delivering Message. Students' free learning time are mainly concentrated after school breaks, during dinner and before bedtime. So spare time is relatively fixed, but WeChat Public Platform's message delivering time is arbitrary, which is not good for students' regular 
learning. In order not to affect students' learning plan and in order to help students autonomously learn English regularly, time must be fixed when delivering message.

\section{Summary}

With the advancement of informatization campus construction, WeChat Public Platform will greatly change the existing features of college English teaching. WeChat Public Platform college English teaching represents the trend of network interactive teaching and also greatly enriches the teaching content of college education. Converting WeChat Public Platform into English teaching tools greatly improves the flexibility of college English teaching and promotes the formation of college students' autonomous learning and cooperative learning atmosphere ${ }^{[2]}$. As college English teachers at the frontier, we should boldly try new teaching auxiliary means, take the initiative to adapt to the trend of the informationization teaching and promote the healthy development of college English teaching.

\section{Acknowledgements}

This work was financially supported by the 2017 Scientific Research Project of Hubei Provincial Department of Education: Study on Mobile English Learning and Teaching Mode in Mobile Internet Environment. Item number:17Q104.

\section{References}

[1] Chai Yangli. An Empirical Study on English Listening and Learning Demands of Non-English Majors Based on WeChat [J]. Electrochemical Education Research, 2014.

[2] Hu Xiaojuan. The Application of WeChat Software in College English Teaching[J]. Journal of Jinan Vocational College, 2014.

[3] Jiang Hongmei. The Application of WeChat in College English Teaching [J]. Journal of Shunde Vocational and Technical College, 2013.

[4] Yin Yilan. The Study of CET-4 Mobile Learning under the Guidance of Micro-Learning Theory -an Empirical Study Based on WeChat Public Platform [J]. Horizon of Science and Technology,

[5] Zhang Xiumei. Study on Hybrid Learning Based on WeChat [D]. Hebei University, 2014.

[6] Tencent. WeChat User Data Report in 2015[Z]. 2015-06-17

[7] Holotescu, C., V, Cretu,\&G, Grosseck. Microblogging Architecture and Scenarios for Learning in Mobile [J]. Social arid Behavioral Sciences, 2014.

[8] Stockwell, G. Using Mobile Phones for Vocabulary Activities Examining the Effect of the Platform [J]. Language \& Technology, 2010

[9] Zhang Zuochen\&Xue Ying. An Investigation of How Chinese University Students Use Social Software for Learning Purposes [J]. Procedia -Social and Behavioral Sciences, 2015.

[10] https://en.wikipedia.org/wiki/Social-media. 